\title{
PEMBERDAYAAN (PEMUDA) KARANG TARUNA DALAM MENINGKATKAN DAN MENUMBUHKAN MINAT BISNIS KREATIF DI DESA GIRI MADIA KECAMATAN LINGSAR KABUPATEN LOMBOK BARAT
}

\author{
Rendra Khaldun \\ Institut Agama Islam Negeri Mataram \\ E-mail: rakha1@ymail.com
}

\begin{abstract}
Abstraksi: Banyaknya angka pengangguran mengindikasikan kurang relevansinya pendidikan dengan dunia nyata dan minimnya ketrampilan yang berorientasi pada kecakapan hidup (life skill). Tujuan kegiatan ini adalah untuk memberdayakan Karang Taruna Desa Giri Madia dengan memberikan pelatihan life skill kepada Karang Taruna Desa Giri Madia sebagai bentuk kepedulian IAIN Mataram terhadap pengembangan kreatifitas para pemuda untuk meningkatkan kesejahteraan serta potensi yang dimiliki. Pelaksanaan kegiatan ini dimulai berdasarkan jadual yang sudah dibuat bersama dengan Kepala Desa Giri Madia dan Karang Taruna. Pelaksanaan kegiatan ini dilaksanakan selama tiga hari. Untuk lebih jelasnya akan di deskripsikan kegiatan yang dilakukan. Materi pertama yang diberikan pada pengantar ini adalah bagaimana melakukan pendataan terhadap orang pemuda yang ada di Desa Giri Madia guna mengidentifikasi kebutuhan program, penentuan narasumber, dan penyusunan jadwal kegiatan. Hasil kegiatan ini menunjukkan bahwa kegiatan ini mampu meningkatkan dan menumbuhkan semangat wirausaha para pemuda sehingga mereka memiliki sense of interpreneuership sejak dini, mampu melihat peluang usaha serta mampu menjadi lebih sejahtera.
\end{abstract}

Kata Kunci: Pemberdayaan, Karang Taruna, Minat, Bisnis Kreatif.

\section{PENDAHULUAN}

Banyaknya angka pengangguran mengindikasikan kurang relevansinya pendidikan dengan dunia nyata dan minimnya ketrampilan yang berorientasi pada kecakapan hidup (life skill). Pendidikan kecakapan hidup (life skill), sebagaimana dijabarkan oleh tim BBE Depdiknas ada lima bidang life skill, yaitu self awareness ( kecakapan mengenal diri), thingking skills (kecakapan berpikir), social skills (kecapakan sosial), academic skills (kecakapan akademik), dan vocational skills (kecakapan vokasional). Kelima bidang ini sangat penting peranannya guna keberhasilan pendidikan yang memiliki relevansi positif dengan dunia nyata.Sayangnya, tolok ukur kecakapan dalam kurikulum kita lebih memprioritaskan pada kecakapan akademik, sementara kecakapan lainnya sangat kurang. Padahal, untuk membekali generasi muda mempunyai wawasan yang luas tentang dunia kerja maupun dunia kemasyarakatan (mengurangi pengangguran) semua kecakapan skill tersebut harus dimiliki oleh generasi muda, utamanya vocational skill. 
Pengembangan kualitas, keterampilan, kepribadian dan kecakapan hidup (life skill) kepribadian generasi muda jelas tidak bisa dicapai hanya dengan mengikuti pendidikan formal, tetapi dapat dilakukan melalui wadah (lembaga atau organisasi) yang mempunyai komitmen terhadap pengembangan generasi muda tersebut. Peran serta organisasi kepemudaan tersebut sebagai salah satu komponen partisipasi sosial masyarakat perlu ditingkatkan dan dikembangkan karena organisasi tersebut mitra potensial pemerintah dalam upaya mengurangi dan memecahkan masalah-masalah sosial. Sejalan dengan hal tersebut, organisasi lokal sebagai sumber daya potensial dituntut untuk berperan secara optimal untuk menggerakkan masyarakat dalam pembangunan. Organisasi lokal di lingkungan desa/kelurahan merupakan wadah untuk memenuhi kebutuhan ataupun memecahkan permasalahan masyarakat Salah satu organisasi lokal yang ada di hampir setiap desa atau kelurahanadalah Karang Taruna sebagai tempat atau wadah pembinaan generasi muda.

Karang Taruna merupakan wadah bagai generasi muda (baik siswa, mahasiswa) untuk berorganisasi sejak dini. Melalui Karang Taruna berbagai macam pendapat dan kerativitas dapat disalurkan termasuk pemberian bekal kecakapan hidup life skill) Tugas pokok dan fungsi Karang Taruna adalah sebagai wahana pengembangan generasi muda (termasuk di dalamnya adalah pemberdayaan remaja). Berdasar hal tersebut keberadaan Karang Taruna sebagai organisasi sosial wadah pengembangan generasi muda mempunyai posisi yang cukup strategis dan semakin diperlukan dalam menjawab permasalahan sosial yang salah satunya adalah masalah pengangguran.

Upaya pengembangan organisasi Karang Taruna dalam bentuk pelatihan sebenarnya sudah dilakukan lebih dari tiga dasawarsa. Namun bentuk pelatihan dan kegiatan hanya bersifat sesaat, berupa diklat dan tidak berkelanjutan. Berdasarkan hal tersebut, dalam penelitian ini ditawarkan sebuah model pemberdayaan Karang Taruna yang bersifat kontinyu (berkelanjutan) dengan membentuknya menjadi young entrepreneur (wirausaha muda).

Beberapa alasan dipilihnya kewirausahan sebagai solusi mengurangi pengangguran karena seorang wirausaha adalah 1) pencipta lapangan kerja baru baik bagi dirinya maupun bagi orang lain; 2) pencipta penghasilan baru baik bagi dirinya maupun bagi masyarakat; 3) pembayar pajak baru yang sangat diperlukan 
oleh pemerintah untuk pembangunan infrastruktur, pendidikan dan kesehatan;4) penghasil devisa bagi wirausaha yang bergerak dibidang ekspor; 5) pemutar roda ekonomi karena kegiatannya antara lain dalam produksi dan pemasaran; 6) pendorong lahirnya wirausaha baru; 7) sumber dan pengguna kreativitas dan inovasi sehingga dapat menghasilkan pembaharuan dalam segala bidang seperti antara lain dalam bidang produksi, manajemen dan pemasaran. Yang terakhir, seorang wirausaha adalah pelaku fungsi sosial, yaitu melaksanakan corporate social responsibility. Seperti pendirian fasilitas pendidikan, kesehatan, keagamaan yang dibangun oleh perusahaan swasta.

Fokus pembinaan kewirausahaan ini diarahkan kepada anggota Karang Taruna (generasi muda) . Hal ini dengan beberapa pertimbangan yaitu, (1) generasi muda memiliki pengetahuan dan wawasan yang lebih luas sehingga memungkinkan menjadi technopreneur, yaitu wirausaha yang berbasis ilmu dan teknologi sehingga dapat mempunyai keunggulan; 2) generasi muda memiliki kemampuan yang lebih baik dalam menghadapi risiko dan cara-cara untuk mengatasinya; 3) generasi muda memiliki kemampuan yang lebih tinggi dalam memanfaatkan fasilitas-fasilitas yang disediakan pemerintah, dan 4) generasi muda dapat lebih mudah untuk mempelajari hal-hal yang baru.

Karang Taruna sebagai wadah pemberdayaan generasi muda mempunyai posisi yang cukup strategis dan semakin diperlukan dalam menjawab permasalahan pengangguran dan kemiskinan. Karang taruna merupakan organisasi sosial kemasyarakatan sebagai wadah dan sarana pengembangan setiap angggota yang memiliki tugas pokok secara bersama sama dengan Pemerintah menyelenggarakan pembinaan generasi muda dan kesejahteraan sosial.

Karang Taruna Desa Giri Madia memiliki peran strategis dalam pembangunan kesejahteraan sosial karena keberadaan Karang Taruna yang berada hampir diseluruh desa/kelurahan bersentuhan langsung dengan penyandang masalah kesejahteraan sosial maupun potensi dan sumber kesejahteraan sosial lainnya. Pemerintah menyadari bahwa tanpa peran serta masyarakat mustahil permasalahan sosial dapat ditangani, untuk itu diharapkan peran serta seluruh potensi dan sumber kesejahteraan sosial termasuk diantaranya Karang Taruna.

Namun dibalik potensi yang dimiliki, peranan karang taruna Desa Giri Madia dewasa ini cederung mandul. Permasalahan kurangnya aktivitas yang produktif 
membuat eksistensi keberadaan karang taruna menjadi sekadar nama besar organisasi kepemudaan. Lemahnya kelembagaan pengurus karang taruna dalam mengoptimalkan potensi yang dimiliki anggotanya menjadi permasalahan yang paling menonjol di karang taruna. Hal ini diperparah dengan kurangnya daya tawar yang terkesan menjanjikan pada organisasi kepemudaan ini, sehingga generasi muda tidak bisa melihat pentingnya eksis dalam organisasi ini.

Dari realitas inilah maka kami sebagai dosen pembimbing KKP di Desa Giri Madia merasa terpanggil untuk memberdayakan Karang Taruna Desa Giri Madia dengan memberikan pelatihan life skill kepada Karang Taruna Desa Giri Madia sebagai bentuk kepedulian IAIN Mataram terhadap pengembangan kreatifitas para pemuda untuk meningkatkan kesejahteraan serta potensi yang dimiliki.

Sebagai wadah bagi remaja, karang taruna memiliki berbagai permasalahan dan hambatan dalam pelaksanaan kegitannya. Berdasarkan data di lapangan dan wawancara mendalam, hambatan utama karang taruna berasal dari internal maupun eksternal. Hambatan internal kegiatan karang taruna di antaranya adalah sedikitnya anggota yang aktif, program kegiatan yang sifatnya insidental dan tidak rutin, dan permasalahan klasik yaitu pendanaan.

Hambatan internal ini terjadi karena beberapa hal. Sedikitnya anggota yang aktif ini karena terkendala beberapa masalah, seperti kesibukan karena masih sekolah, maupun kesibukan karena urusan rumah tangga. Adapun hambatan eksternal berasal dari institusi atau lembaga terkait pengembangan potensi karang taruna. Menurut pengakuan pengurus karang taruna, hambatan utama adalah masalah pendanaan. Selama ini karang taruna kurang terdengar gaung kegiatannya karena minimnya dana. Masih menurut pengurus karang taruna, pihaknya pernah mengajukan proposal kegiatan karang taruna ke beberapa pihak namun masih mengalami kegagalan.

\section{PEMBAHASAN}

\section{Pembelajaran di luar Kelas}

Pendekatan pembelajaran di luar kelas (outdoor study) adalah sebuah pendekatan pembelajaran yang menggunakan suasana di luar kelas sebagai situasi 
pembelajaran berbagai permainan sebagai mendia transformasi konsep-konsep yang disampaikan dalam pembelajaran. ${ }^{21}$

Pendekatan pembelajaran di luar kelas menggunakan beberapa metode seperti penugasan, tanya jawab, dan belajar sambil melakukan atau mempraktekkan dengan situasi belajar sambil bermain. Pendekatan pembelajaran diluar kelas ini memiliki kelebihan yang mendukung pada pembelajaran siswa, di antaranya sebagai berikut:

1. Mendorong motivasi belajar siswa, karena menggunakan setting alam terbuka sebagai sarana kelas, untuk memberikan dukungan proses pembelajaran secara menyeluruh yang dapat menambah aspek kegembiraan dan kesenangan

2. Guru mampu menciptakan suasana pembelajaran yang menyenangkan karena dapat berekspolarasi menciptakan suasana belajar seperti bermain

3. Pada pembelajaran di luar kelas siswa menggunakan media pembelajaran yang kongkrit dan memahami lingkungan yang ada disekitarnya. Pada saat pembelajaran digunakan media yang sesuai dengan situasi kenyataannya, yakni berbagai permainan anak seperti seluncuran, ayunan, jungkat-jungkit dan lainlain

4. Mengasah aktivitas fisik dan kreativitas siswa karena menggunakan strategi belajar sambil melakukan atau mempraktekan sesuai dengan penugasan. Selain memiliki kelebihan, pendekatan di luar kelas sebagai pendekatan pembelajaran juga memiliki kelemahan: memerlukan perhatian yang ekstra dari guru pada saat pembelajaran karena menggunakan media yang sesuai dengan kenyataannya di arena bermain anak yang dapat memungkinkan anak keterusan bermain di tempat tersebut.

Pembelajaran di luar kelas (outdoor study) merupakan pembelajaran yang dilakukan di luar ruang kelas atau di luar gedung sekolah, atau berada di alam bebas, seperti: bermain di lingkungan sekitar sekolah, di taman, atau di perkampungan masyarakat sekitar sehingga diperoleh pengetahuan dan nilai-nilai yang berkaitan dengan aktivitas hasil belajar terhadap materi yang disampaikan di luar kelas. Pendekatan pembelajaran di luar kelas (Outdoor study) adalah

${ }^{21}$ Ginting, Outdoor Learning, (Bandung: P3GT Hosnan, 2014), h. 37. 
pendekatan yang dilakukan guru, dimana guru mengajak siswa belajar di luar kelas untuk melihat peristiwa langsung di lapangan yang di gunakan sebagai sumber belajar. Peran guru disini adalah sebagai motivator, artinya guru sebagai pemandu agar siswa belajar melalui pengalaman yang mereka peroleh.

Pembelajaran di luar kelas (outdoor study) ini adalah sebagai pendekatan pembelajaran dalam meningkatkan pemahaman lawan kata pada siswa. Karena dengan pembelajaran di luar kelas (outdoor study) siswa dapat merasakan pengalaman langsung melalui pengalaman sendiri di luar kelas terhadap suatu objek di lingkungan untuk meningkatkan pemahaman anak tersebut. Melalui sudut pandang kependidikan, aktivitas pendidikan yang dilakukan di luar lingkungan sekolah, setidaknya memuat tiga konsep utama, yaitu konsep proses belajar, aktivitas luar kelas dan lingkungan. Pertama, konsep proses belajar melalui aktivitas luar kelas (outdoor study) adalah proses belajar interdisipliner melalui satu seri aktivitas yang dirancang untuk dilakukan di luar kelas. Pendekatan ini secara sadar mengeksploitir potensi latar alamiah untuk memberi kontribusi terhadap perkembangan fisik dan mental. Dengan meningkatkan kesadaran terhadap hubungan timbal balik dengan lingkungan, program dapat mengubah sikap dan perilaku terhadap lingkungan yang mereka peroleh melalui pengalaman langsung di luar kelas.

Kedua yaitu konsep aktivitas luar kelas merupakan suatu pendekatan dengan menggunakan kehidupan di luar ruangan yang memberikan banyak kesempatan bagi siswa untuk memperoleh dan menguasai berbagai bentuk keterampilan dasar, sikap dan apresiasi terhadap berbagai hal yang terdapat di luar kelas.

Bentuk-bentuk kegiatan luar kelas dapat berupa: menjelajah atau mengamati lingkungan sekitar sekolah, mempelajari sesuatu yang mereka peroleh melalui benda-benda yang ada di sekitar lingkungan dimana kita tinggal dan lain sebagainya. Konsep lingkungan yang merujuk pada eksplorasi ekologi sebagai andalan mahluk hidup yang saling tergantung antara yang satu dengan yang lain. Pentingnya lingkungan tidak hanya dijadikan sebagai tempat belajar melainkan lingkungan juga dapat dijadikan sebagai sumber belajar yang mereka peroleh dari lingkungan tersebut, melalui pengalaman langsung di luar kelas proses pembelajaran tidak hanya di lakukan di dalam kelas melainkan lingkungan di luar 
kelas yang dapat lebih meningkatkan hasil belajar siswa pada suatu materi pembelajaran.

Pendekatan pembelajaran dapat di artikan sebagai titik tolak atau sudut pandang kita terhadap proses pembelajaran, yang merajuk pada pandangan tentang terjadinya suatu proses yang sifatnya masih sangat umum, di dalamnya mewadahi, menginspirasi, menguatkan dan melatari metode pembelajaran dengan cakupan teoritis tertentu. Dilihat dari pendekatannya, pembelajaran terdapat dua jenis pendekatan yaitu: (1) pendekatan yang berorientasi atau berpusat pada siswa (student centered approach) dan (2) pendekatan pembelajaran yang berorientasi atau berpusat pada guru (teacher centered approach).

Strategi pembelajaran adalah suatu kegiatan pembelajaran yang harus dikerjakan guru dan siswa agar tujuan pembelajaran dapat dicapai secara efektif dan efisien. Selanjutnya, dalam strategi pembelajaran terkandung makna perencanaan. Artinya, bahwa strategi pada dasarnya masih bersifat konseptual tentang keputusan-keputusan yang akan di ambil dalam suatu pelaksanaan pembelajaran. Dilihat dari strateginya, pembelajaran dapat dikelompokkan ke dalam dua bagian pula, yaitu: (1) exposition-discovery learning dan (2) group individual learning. Ditinjau dari cara penyajian dan cara pengolahannya, strategi pembelajaran dapat dibedakan antara strategi pembelajaran induktif dan strategi pembelajaran deduktif. 22

Strategi pembelajaran sifatnya masih konseptual dan untuk mengimplementasikannya digunakan berbagai metode pembelajaran tertentu. Dengan kata lain, strategi merupakan "a plan of operation achieving something" sedangkan metode adalah "a way in achieving something". Jadi, metode pembelajaran dapat diartikan sebagai cara yang digunakan untuk menginplementasikan rencana yang sudah disusun dalam bentuk kegiatan nyata dan praktis untuk mencapai tujuan pembelajaran. Terdapat beberapa metode pembelajaran yang dapat digunakan untuk mengimplementasikan strategi pembelajaran, diantaranya: (1) ceramah; (2) demonstrasi; (3) diskusi; (4) simulasi; (5) laboratorium; (6) pengalaman lapangan; (7) brainstorming; (8) debat, (9) simposium, dan sebagainya. Berdasarkan paparan tersebut dapat disimpulkan

22 Wina Senajaya, Strategi Pembelajaran, (Jakarta: Raja Grafindo, 2008), h. 74. 
bahwa pendekatan pembelajaran merupakan titik tolak dari sebuah pembentukan model pembelajaran yang terdiri dari startegi, metode dan teknik pembelajaran.

Tujuan pendidikan yang secara umum ingin dicapai melalui aktivitas di luar ruang kelas atau di luar lingkungan sekolah adalah:

1. Membuat setiap individu memiliki kesempatan unik untuk mengembangkan kreativitas dan inisiatif personal

2. Menyediakan latar (setting) yang berarti bagi pembentukan sikap

3. Mengembangkan kesadaran, apresiasi dan pemahaman terhadap lingkungan alam dan bagaimana manusia memiliki relasi dengan hal tersebut

4. Membantu mewujudkan potensi setiap individu agar jiwa, raga dan spiritnya dapat berkembang optimal

5. Memberikan 'konteks' dalam proses pengenalan berkehidupan sosial dengan memberikan kesempatan bagi anak-anak untuk merasakan secara langsung

6. Memungkinkan siswa mengembangkan keterampilan dan ketertarikan terhadap kegiatan-kegiatan luar kelas

7. Menumbuhkan pemahaman untuk secara bijak menggunakan dan melindungi lingkungan alam

8. Mengenalkan berbagai kegiatan di luar kelas yang dapat membuat pembelajaran lebih kreatif

9. Memberikan kesempatan yang unik untuk perubahan perilaku melalui penataan latar pada kegiatan luar kelas

10. Memberikan kontribusi untuk membantu mengembangkan hubungan gurumurid yang lebih baik melalui berbagai pengalaman di alam bebas

11. Memberikan kesempatan untuk belajar dari pengalaman langsung melalui implementasi bebas kurikulum sekolah diberbagai area

12. Memanfaatkan sumber-sumber yang berasal dari lingkungan dan komunitas sekitar untuk pendidikan

\section{Manfaat Pembelajaran Luar Kelas (Outdoor Learning)}

Model pembelajaran Outdoor Learning bisa diterapkan pada anak-anak usia Sekolah dan orang dewasa sekaligus. Berikut manfaat model pembelajaran outdoor learning menurut para ahli; Menurut suyadi menyebutkan, bahwa manfaat pembelajaran luar kelas antara lain: Pikiran lebih jernih, Pembelajaran akan terasa menyenangkan, Pembelajaran lebih variatif, Belajar lebih rekreatif, Belajar lebih riil, 
Anak lebih mengenal pada dunia nyata dan luas, Tertanam image bahwa dunia sebagai kelas, Wahana belajar akan lebih luar, Kerja otak lebih rileks. ${ }^{23}$

Menurut Sudjana dan Rivai menjelaskan, banyak keuntungan yang dioeroleh dari kegiatan mempelajarai lingkungan dalam proses belajar ${ }^{24}$, antara lain:

1. Kegiatan belajar lebih menarik dan tidak membosankan siswa duduk berja-jam, sehingga motivasi belajar siswa akan lebih tinggi.

2. Hakekat belajar akan lebih bermakna sebab siswa dihadapkan dengan situasi dan keadaan yang sebenarnya atau bersifat alami.

3. Bahan-bahan yang dapat dipelajari lebih kaya serta lebih factual sehingga kebenarannya akurat.

4. Kegiatan belajar siswa lebih komprehensif dan lebih aktif sebab dapat dilakukan dengan berbagai cara seperti mengamati, bertanya atau wawancara, membuktikan atau mendemonsrrasikan, menguji fakta, dan lain-lain.

5. Sumber belajar lebih kaya sebab lingkungan yang dapat dipelajari bisa beraneka ragam seperti lingkungan social, lingkungan alam, lingkungan buatan, dan lainlain.

6. Siswa dapat memahami dan menghayati aspek-aspek kehidupan yang ada di lingkungannya, sehingga dapat membentuk pribadi yang tidak asing dengan kehidupan membentuk sekitarnya, serta dapat memupuk cinta lingkungan.

Menurut Direktorat Tenaga Kependidikan proses pembelajaran secara langsung dapat memberikan pengalaman nyata pada sisa, artinya pengalaman itu akan terhindar dari kesalahan persepsi dari pembahasan materi pelajaran tertentu. ${ }^{25}$

Sedangkan Menurut Purwanti nilai plus dari outdoor learning adalah, ${ }^{26}$ sebagai berikut:

1. Dapat merangsang keinginan siswa untuk mengikuti materi pelajaran guna meningkatkan pengetahuan, sikap, dan ketrampilan siswa terhadap mata pelajaran bahasa Indonesia.

${ }^{23}$ Husamah, Pembelajaran Luar Kelas Outdoor Learning/PRT, (Jakarta: Prestasi Pustaka Raya, 2013), h. 25

${ }^{24}$ Ibid.,

${ }^{25}$ Ibid., h. 26.

${ }^{26}$ Ibid., h.26. 
2. Dapat digunakan sebagai media alternatif bagi guru dalam mengembangkan metode mengajar mata pelajaran bahasa Indonesia.

3. Model pembelajaran outdoor learning memberikan alternatif cara pembelajaran dengan membangun makna atau dengan melibatkan lebih banyak indera penglihatan, indera pendengaran, indera perabaan, indera penciuman padasiswa dan memberikan pengalaman yang lebih berkesan, karena siswa mengalami sendiri tentang materi pelajaran.

Di samping Manfaat di atas terdapat juga manfaat yang lain di antaranya: Pikiran siswa lebih segar dan jernih, Pembelajaran akan terasa lebih menyenangkan, Pembelajaran lebih bervariasi, Belajar lebih rekreatif, Belajar lebih nyata, Peserta didik lebih mengenal dunia nyata yang luas, Akan tertanam imaji bahwa dunia merupakan kelas untuk belajar, Wahana belajar akan lebih luas, Kerja otak akan lebih baik sehingga peserta didik menjadi lebih cerdas.

\section{Perbandingan Antara Kegiatan Pembelajaran di Luar Kelas (Outdoor Learning) dan Dalam Kelas (Indoor Learning)}

Terkait dengan perbandingan Antara Kegiatan Pembelajaran di Luar Kelas (Outdoor Learning) dan Dalam Kelas (Indoor Learning), berikut akan digambarkan melalui tabel:

\begin{tabular}{|c|c|c|}
\hline Domain & Dalam Kelas (Indoor) & Luar Kelas (Outdoor) \\
\hline $\begin{array}{l}\text { Mendorong Motivasi } \\
\text { Betajar }\end{array}$ & $\begin{array}{l}\text { Belajar dibatasipenataan } \\
\text { ruang, Kaku dan cendrung } \\
\text { lenuh }\end{array}$ & $\begin{array}{l}\text { Eelajartanpa dibatasi ruang, } \\
\text { eiswa berberakbebae }\end{array}$ \\
\hline $\begin{array}{l}\text { Suanana Belajar yang } \\
\text { menyenangkan }\end{array}$ & Sarana belaiar minim & $\begin{array}{l}\text { Eelaiar aambil bermain, } \\
\text { menielaiah, rekreasi. } \\
\text { meneliti, dan observasi. }\end{array}$ \\
\hline $\begin{array}{l}\text { Mengasah Aktivitas Fisik } \\
\text { dan kroativitas }\end{array}$ & $\begin{array}{l}\text { Pemahaman kadana keliru } \\
\text { dengan kenvataan Karena } \\
\text { minimnyapraktik. }\end{array}$ & $\begin{array}{l}\text { Belajar dengan melakukand } \\
\text { mempraktikkan/merlibatkan } \\
\text { otak dan badan }\end{array}$ \\
\hline $\begin{array}{l}\text { Pengaunaan media } \\
\text { Dembelajaran yg konkret }\end{array}$ & Manipulatif/ Hiruan/ replika & $\begin{array}{l}\text { Sesui dengn situasi dan } \\
\text { Eenyataan }\end{array}$ \\
\hline $\begin{array}{l}\text { Penguasaan ketrampilan } \\
\text { dasar, sikap dan apresiasi. }\end{array}$ & $\begin{array}{l}\text { Balian konsep umum dan } \\
\text { cendrungabstrak. }\end{array}$ & $\begin{array}{l}\text { Menielajah dan mengemati } \\
\text { lingkungan pengetahuan. } \\
\text { diperoleh dari pengamatan }\end{array}$ \\
\hline $\begin{array}{l}\text { Penguasaan ketrampilan } \\
\text { sostal }\end{array}$ & $\begin{array}{l}\text { Ruang ketam hanya sebacai } \\
\text { tempat belaiar, puksen. } \\
\text { sumber bolalar. }\end{array}$ & $\begin{array}{l}\text { Keterampitan bidus dan keria } \\
\text { gama, mengemukakan } \\
\text { Dendabat, toleransi }\end{array}$ \\
\hline $\begin{array}{l}\text { Mengembangkan sikap } \\
\text { mandiri }\end{array}$ & $\begin{array}{l}\text { Sikap ketergantungan pada } \\
\text { ouru }\end{array}$ & Tidak tergantung pada guru \\
\hline $\begin{array}{l}\text { Hasil belajar permanen di } \\
\text { otak }\end{array}$ & $\begin{array}{l}\text { Belajar hanya memahami } \\
\text { tnapa praktik sehingga } \\
\text { anak mudah lupa }\end{array}$ & $\begin{array}{l}\text { Belajar dengan mencoba, } \\
\text { merasakan, mencari, menulis } \\
\text { menelaah, melakukan } \\
\text { eksperimentasi, menerapkan } \\
\text { dan melaporkan. }\end{array}$ \\
\hline Keterampilan Intelektual & $\begin{array}{l}\text { Belajar di dalam kelas } \\
\text { bersifat doktriner/ dekte }\end{array}$ & $\begin{array}{l}\text { Mendefinisikan, } \\
\text { mengklasifikasikan, menquii } \\
\text { hipotesis, menghubunakan } \\
\text { pengalaman masa lalu, menarik } \\
\text { kesimpulan, melihat sebab } \\
\text { akibat, dan membandingkan } \\
\text { pandangan2 yg berbeda. }\end{array}$ \\
\hline $\begin{array}{l}\text { Mendekatkan hubungan } \\
\text { emosional antara guru dan } \\
\text { siswa }\end{array}$ & $\begin{array}{l}\text { Karena suasana formal } \\
\text { jadi antara guru dan siswa } \\
\text { memiliki iarak }\end{array}$ & $\begin{array}{l}\text { Keakraban bisa terialin dalam } \\
\text { suasanayg rileks }\end{array}$ \\
\hline $\begin{array}{l}\text { Meaningful learning/ } \\
\text { berlajar menjadi bermakna }\end{array}$ & $\begin{array}{l}\text { Interaksi dengan sumber } \\
\text { belajarsangat minim }\end{array}$ & $\begin{array}{l}\text { Belajar dari keadaan yg } \\
\text { sebenarnya dilakuakn dengan } \\
\text { mengamatai, wawancaraa, } \\
\text { membuktikan sesuatu, menguii } \\
\text { fakta }\end{array}$ \\
\hline
\end{tabular}




\section{Mata Pelajaran yang Dapat Diajarkan Di Luar Kelas (Outdoor Learning) dan Cara Penerapannya.}

Mata Pelajaran yang dapat diajarkan di Luar Kelas dan cara penerapannya, antara lain: Bahasa Indonesia (Membaca puisi, Diskusi, Mengarang cerita, Permainan), Ilmu Pengetahuan Alam (Guru mengajak siswa keluar kelas ketempat yang teduh dan menyehatkan untuk kegiatan belajar, Mengajak siswa ke taman atau lingkungan sekitar sekolah dan menyebutkan tumbuhan dikotil dan monokotil Siswa diajak ke kebun binatang, Ilmu Pengetahuan Sosial (Siswa diajak jalan-jalan ke pantai asuhan Membuat permainan, Siswa diajak jalan-jalan ke sekitar sekolah), PKN (Materi tolong-menolong, siswa diajak ke PMI Membawa siswa ke halaman kelas lain (berdekatan) kemudian menyetel musik dan berbincang-bincang ditempat tersebut, Tentang toleransi di luar kelas, dengan cara mengajak siswa ke tempat ibadah, gereja, masjid, vihara, pura dll, Biologi (Siswa diajak ke kandang sapi Memanfaatkan lingkungan di luar kelas Berkunjung ke kebun binatang), Matematika (Mengajak siswa ke warung dekat sekolah Mengukur tinggi tumbuhan, pohon kecil di halaman depan sekolah Menghitung kecepatan lari di lapangan), Bahasa Inggris (Ajak siswa ke taman, sebutkan bahasa inggris dari masing-masning tanaman tersebut Mengajak siswa ke tempat wisata yang ada orang asingnya).

Dalam rangka penerapan pendekatan pembelajaran di luar kelas beberapa metode dapat digunakan, di antaranya: Metode Penugasan, Metode Tanya jawab, Metode Bermain Metode Observasi. Lingkungan Dalam Sekolah (halaman sekolah, taman bunga disekolah, pohon pohon, lapangan, halamnan belakang sekolah, koperasi, dan kolam yg ada disekitar sekolah). Lingkungan Luar Sekolah (Persaawahan, kebun binatang, museum, perusahaan, sungai, laut, perkebunan, danau, pegunungan, rumah ibadah, pantai asuhan anak yatim, panti jompo, warung, pasar, pemukiman penduduk, kandang hewan, taman, hutan, cagar alam, objek pariwisata, jembatan)

Terdapat beberapa peran guru yang dapat dilakukan ketika menerapkan pembelajaran di luar kelas, di antaranya: sebagai Fasilitator, Sebagai Teman, Sebagai Pelatih, Sebagai, Motivator.

Sejak tahun 1997-1998 Indonesia mengalami krisis ekonomi yang sangat parah dan menjadikan kondisi perekonomian negara kita semakin sulit. Banyak perusahaan yang terpaksa gulung tikar dan merumahkan ribuan karyawannya. 
Dampaknya bagi negara yang termasuk dalam negara yang sedang berkembang seperti Indonesia, kemiskinan yang ditandai dengan banyaknya pengangguran, daya beli masyarakat yang rendah, tingkat kesejahteraan yang kecil, tingkat kesehatan yang rendah dan angka pendidikan yang semakin menurun menjadi sebuah kondisi yang tidak terelakkan.

Akibat krisis ekonomi tersebut tidak hanya dirasakan oleh mereka yang tinggal di kota-kota saja, namun hampir semua sendi masyarakat, termasuk masyarakat yang tinggal di pedesaan. Sementara di sisi yang lain kita ketahui bahwa desa menyimpan kekayaan yang luar biasa, yang apabila ditangani secara serius dan profesional dapat menjadi lahan pemasukan yang tidak sedikit. Hanya saja, mungkin kepekaan dari masyarakat desa dirasakan masih kurang sehingga potensi yang besar tadi hanya terabaikan begitu saja.

Untuk mengatasi permasalahan tersebut ada salah satu solusi yang bisa dilaksanakan yaitu melalui penggalian potensi yang dimiliki desa. Potensi tersebut dapat berupa sumber daya alam, jumlah penduduk dengan usia produktif yang besar, dan lain-lain. Modal dasar yang telah dimiliki tadi, dapat dimanifestasikan ke dalam usaha-usaha yang bersifat produktif, pembinaan kewirausahan yang belum ada maupun peningkatan kewirausahaan yang selama ini telah eksis. Masyarakat desa harus diyakinkan bahwa mereka sebenarnya mampu dan layak mendapat tingkat kesejahteraan yang lebih tinggi.

Hanya saja, upaya-upaya produktif yang berasal dari desa harus ditumbuhkembangkan agar tidak berhenti di tengah jalan. Oleh karena itu, perlu adanya pembinaan kepada masyarakat yang berkesinambungan. Keberadaan pihak-pihak yang terkait sangat diperlukan, misalnya tambahan modal, perluasan pemasaran, peningkatan kemampuan dalam berusaha/berwirausaha (management) dan sebagainya.

Secara sederhana seorang wirausaha adalah adalah seseorang yang mampu mengatur, menjalankan, menanggung resiko bagi pekerjaan-pekerjaan yang ditempuhnya dalam dunia usaha. Para wirausahawan dengan sifat alamiahnya tidak mengenal golongan karena di dapat berupa seorang laki-laki muda yang menjual kaset musiknya di pasar, seorang wanita muda yang menjual hasil lilin hasil buatannya sendiri, atau sepasang suami istri yang memasok barang-barang kebutuhan rumah tangga. Dia bisa bekerja sendirian seperti mengambil barang 
dagangan dan menjualnya di pasar-pasar atau bisa mengolah hasil panen di desanya untuk dipasarkan dalam bentuk yang berbeda dari aslinya. Yang terpenting adalah tidak menggantungkan hidupnya dengan orang lain, dia bersifat mandiri dan memenuhi kebutuhannya sendiri.

Seorang wirausahawan dapat berkembang dari minat atau bakat yang mereka miliki, akan tetapi kreatifitas dalam berusaha justru akan membantu kelancaran usahanya. Ada beberapa watak seorang wirausahawan yang harus dipahami dalam menjalankan sebuah usaha, seperti:

1. Disiplin diri, yaitu selalu berpegang teguh komitmen atau mematuhi aturan yang dibuatnya sendiri.

2. Rincian, yaitu usaha-usaha kreatif yang selalu belajar mendisiplinkan diri untuk berurusan dengan rincian-rincian sepeti keuangan, pendataan/administrasi dan pembuatan rencana-rencana kegiatan.

3. Menghargai, yaitu memberikan penghargaan atas hasil yang diterima. Guna watak ini adalah selalu memberikan kesempatan untuk mengembangkan diri dan menghargai hasil karya.

4. Kreativitas, yaitu semakin kita berbeda dalam menghasilkan sebuah produk yang dibutuhkan pasar akan berkecenderungan untuk diminati.

5. Bentuk atau Gaya, yaitu bagaimana seorang wirausahawan akan membentuk karakter diri dan produk yang membedakan dengan orang dan produk lain.

6. Keluwesan, yaitu mampu untuk menyesuaikan diri dan mampu melihat berbagai cara pemecahan suatu masalah.

7. Dorongan, yaitu motivasi untuk mencapai keberhasilan.

8. Komitmen, yaitu keteguhan untuk melakukan sesuatu yang kita yakini.

Wirausaha merupakan potensi pembangunan, baik dalam jumlah maupun dalam mutu wirausaha itu sendiri. Sekarang ini kita menghadapi kenyataan bahwa jumlah wirausahawan Indonesia masih sedikit dan mutunya belum bisa dikatakan hebat, sehingga persoalan pembangunan wirausaha Indonesia merupakan persoalan mendesak bagi suksesnya pembangunan. Jika Kita perhatikan manfaat adanya wirausaha banyak sekali.

Sekarang ini, banyak anak muda mulai tertarik dan melirik profesi bisnis yang cukup menjanjikan masa depan cerah. Kaum remaja zaman sekarang, dengan latar belakang profesi orang tua yang beraneka ragam mulai 
mengarahkan pandangannya ke bidang bisnis. Hal ini didorong oleh kondisi persaingan di antara pencari kerja yang mulai ketat. Lowongan pekerjaan mulai terasa sempit.

Sekarang ini orang tua sudah tidak berpandangan negatif lagi pada dunia bisnis. Anak-anak muda tidak lagi "malu" berdagang. Bahkan para artis banyak terjun ke dunia "bisnis" perdagangan berbagai komoditi.

Seorang wiraswasta ialah seseorang yang memiliki pribadi hebat, produktif, kreatif, melaksanakan kegiatan perencanaan bermula dari ide sendiri, kemudian mengembangkan kegiatannya dengan menggunakan tenaga orang lain dan selalu berpegang pada nilai-nilai disiplin dan kejujuran yang tinggi.

Suatu analisis kelayakan yang komprehensif dan sistematis hendaknya mampu mengidentifikasi masalah di atas jika ada, dan menunjukkan cara untuk mengendalikannya. Rangkuman di atas menyatakan syarat-syarat yang penting bagi keberhasilan usaha baru di masa depan, pengetahuan pasar yang memadai, produk yang kompetitif yang menjalankan fungsinya dengan baik, kesadaran akan situasi persaingan, basis finansial yang memadai dengan strategi investasi yang tepat, serta waktu memulai usaha yang tepat.

\section{Pelaksanaan Kegiatan Pemberdayaan Karang Taruna}

Program Pemberdayaan (Pemuda) Karang Taruna dalam Meningkatkan dan Menumbuhkan Minat Bisnis Kreatif di Desa Giri Madia Kecamatan Lingsar Kabupaten Lombok Barat ini sebenarnya bukan hanya ditujukan kepada anggota Karang Taruna saja akan tetapi juga diperuntukkan bagi masyarakat yang ada di Desa Giri Madia. Hal ini dilakukan agar masyarakat ikut andil dalam meningkatkan perekonomian masyarakat yang ada di Desa Giri Madia Kecamatan Lingsar Kabupaten Lombok Barat.

Pelaksanaan kegiatan Pemberdayaan (Pemuda) Karang Taruna dalam Meningkatkan dan Menumbuhkan Minat Bisnis Kreatif di Desa Giri Madia Kecamatan Lingsar Kabupaten Lombok Barat dilaksanakan dalam bentuk pelatihan yang melibatkan anggota karang taruna, pengurus karang taruna, dan pemuda serta 
masyarakat dengan tahapan-tahapan pelaksanaan sebagaimana yang akan dideskripsikan selanjutnya.

1. Tahap Perencanaan dan Pelaksanaan Program Pemberdayaan Stakeholders

Tujuan penyelenggaraan program pemberdayaan stakeholders merupakan upaya memberikan pengetahuan, pemahaman, kesadaran dan kemampuan kepada orangtua, masyarakat, tokoh agama, tokoh pemuda, dan pemerintah desa dalam meningkatkan perekonomian mereka berdasarkan keunggulan komparatif dan komptitif yang ada di Desa Giri Madia.

Tujuan utama inilah yang akan menjadi tugas pokok lembaga dalam pelaksanaan program parenting berbasis kecakapan sosial. Harapannya, orangtua merasa memahami, memiliki program dan dengan sukarela ikut terlibat dalam kegiatan yang akan membantu para pemuda dalam memperolah pemahaman dan pengetahuan untuk mengembangkan ekonomi produktif yang dapat memenuhi kesejahteraan hidup mereka pada masa muda. Adapun tahapan program ini terdiri dari:

a. Tahap Persiapan

Tahap persiapan merupakan tahapan paling awal sebelum pelaksanaan program pemberdayaan karang taruna dilaksanakan, adapun pada tahap persiapan ini, pengelola melakukan beberapa hal diantaranya :

1) Sosialisasi program Pemberdayaan Karang Taruna. Guna memaksimalkan kegiatan yang dilaksanakan, langkah pertama yang dilakukan pada tahap persiapan ini adalah melakukan sosialisasi kepada para pemuda baik yang putus sekolah atau tidak dibantu oleh Pengurus Karang Taruna Desa Giri Madia Kecamatan Lingsar dan mahasiswa KKP IAIN Mataram Desa Giri Madia. Adapun tahapan dalam sosialisasi ini adalah sebagai; Mengadakan sosialisasi tentang program yang akan dilaksanakan kepada para pemuda yang ada di Desa Giri Madia Kecamatan Lingsar, Rekrutiment peserta dilaksanakan melalui pengurus Karang Taruna Desa Giri Madia baik secara perorangan maupun secara serempak atau kolektif, Menetapkan nama peserta yang akan dilaksanakan seperti: nama, tempat/tanggal lahir, pendidikan, alamat, dan sebagainya; 
2) Menentukan narasumber. Narasumber dalam kegiatan ini dipilih berdasarkan keahlian dan kemampuan yang dimiliki terkait dengan tema pelatihan yang dilaksanakan sehingga benar-benar tepat sasaran dan aplikatif.

3) Jadwal pelaksanaan kegiatan. Jadwal kegiatan disusun berdasarkan kesepakatan yang dibuat oleh peserta dengan pengelola (karang taruna dan kepala desa) tentang kapan dan dimana kegiatan ini akan dilaksanakan agar kegiatan dapat berjalan dengan baik dan maksimal.

b. Tahapan Pelaksanaan Kegiatan

Pelaksanaan kegiatan ini dimulai berdasarkan jadual yang sudah dibuat bersama dengan Kepala Desa Giri Madia dan Karang Taruna. Pelaksanaan kegiatan ini dilaksanakan selama tiga hari. Untuk lebih jelasnya akan di deskripsikan kegiatan yang dilakukan.

Materi pertama yang diberikan pada pengantar ini adalah bagaimana melakukan pendataan terhadap orang pemuda yang ada di Desa Giri Madia guna mengidentifikasi kebutuhan program, penentuan narasumber, dan penyusunan jadwal kegiatan.

Kemudian langkah selanjutnya yang harus dilakukan oleh penyelenggara dalam melakukan pendataan adalah:

1. Pengurus karang taruna mendata latarbelakang peserta yang akan mengikuti program yang akan dilaksanakan.

2. Pengurus karang taruna menyiapkan penanggung jawab keberlangsungan program setelah kegiatan pemberdayaaan dilakukan.

3. Pengurus karang taruna menyusun program-program kegiatan sekaligus nara sumber yang akan dilakukan untuk kegiatan pasca pelatihan.

4. Pembentukan Pengurus penanggungjawab pasca kegiatan yang bertujuan untuk memudahkan keterlibatan pemuda yang akan mengikuti kegiatan dibantu oleh karang taruna dapat membentuk kepengurusan dengan kesepakatan bersama sebagai berikut: Ketua, Sekretaris, Bendahara, Tim Pelaksana

Penetapan Susunan kepengurusan pasca pemberdayaan dengan jangka waktu tugas selama satu tahun atau dapat disepakati bersama sesuai dengan 
kebutuhan dan kesepakatan.Tujuan pembentukan kepengurusan dalam penyelenggaraan pendampingan pasca pelatihan adalah untuk memberikan beban tanggung jawab antara pengelola dan masyarakat. Keterlibatan tokoh masyarakat/tokoh agama/tokoh pemuda lainnya yang disegani dan perduli dengan pemberdayaan ekonomi produktif juga diperlukan.

\section{Pengembangan Desa Inovasi Giri Madia Kecamatan Lingsar Kabupaten Lombok Barat" (Warna, Sekretaris Desa Giri Madia)}

Sekretaris Desa yang menjadi narasumber pada acara ini memulai penjelasannya dengan memberikan beberapa stressing terkait dengan desa Giri Madia. Narasumber menekankan agar Desa Giri Madia dapat menjadi desa inovasi di Kecamatan Lingsar Kabupaten Lombok Barat. Oleh sebab itu ia mulai menjelaskan hal-hal yang terkait dengan desa inovasi dengan memeuli bahasan sebagai berikut:

1. Masalah Desa Saat Ini

a. Adanya keterbatasan akses masyarakat terhadap modal, lahan usaha, input produksi, dan jaringan pemasaran produk.

b. Adanya ketidakpastian jaminan harga produk.

c. Adanya penyediaan pelayanan prasarana dan sarana yang terbatas, disertai dengan standar pelayanan yang masih rendah

d. Adanya pola dan pelaksanaan program-program perdesaan yang tidak terintegrasi.

2. Peluang Dan Tantangan Di Desa Giri Madia

a. Peluang

1) Potensi lahan/SDA yang sangat besar.

2) Permintaan pasar terhadap komoditi pangan.

3) Pemanfaatan lahan/SDA dalam skala besar dan inovatif (tradeable).

b. Tantangan

1) Masyarakat menjadi pemilik, pengelola, dan pekerja dalam kegiatan produksi yang menciptakan kesempatan kerja \& pendapatan terjamin.

2) Hubungan ekonomi desa dengan kota yang saling menguntungkan menjadi basis pengembangan ekonomi perdesaan.

3) Penyediaan proses kegiatan secara sistemik (enablers). 


\section{c. Transformasi}

1) Menciptakan masyarakat desa yang maju dan produktif.

2) Pengembangan Desa Inovasi sebagai pengungkit peningkatan kualitas pembangunan kawasan perdesaan secara terpadu (processes).

\section{KESIMPULAN}

Sebagaimana diketahui bahwa pemberdayaan karang taruna yang dilaksanakan adalah merupakan salah satu bentuk kegiatan pengabdian pada masyarakat yang dilaksanakan di desa Giri Madia Kecamatan Lingsar kabupaten Lombok Barat. Pelatihan ini bertujuan untuk meningkatkan dan menumbuhkan semangat wirausaha para pemuda sehingga mereka memiliki sense of interpreneuership sejak dini, mampu melihat peluang usaha serta mampu menjadi lebih sejahtera.

Penggalian potensi desa untuk dijadikan sebagai salah satu sumber inspirasi dalam menumbuhkan life skill bagi pemuda adalah merupakan hal yang sangat urgent dalam kelangsungan peningkatan ekonomi desa sehingga bisa menjadi desa mandiri dan desa inovasi yang nantinya bisa menjadi produk unggulan desa (one village one product).

\section{DAFTAR PUSTAKA}

Ginting, Outdoor Learning, Bandung: P3GT Hosnan, 2014

Husamah, Pembelajaran Luar Kelas Outdoor Learning/PRT, Jakarta: Prestasi Pustaka Raya, 2013.

Universitas Mercu Buana, Buku Kewirausahaan "Membangun Usaha Sukses Sejak Usia Muda", Jakarta: Salemba Empat, 2011.

Senjaya, Wina, Strategi Pembelajaran, Jakarta: Raja Grafindo, 2008. 